Volume 16, Nomor 2, Desember 2015

\title{
PENGARUH PERCEIVED VALUE TERHADAP KEPUASAN DAN MINAT BELI ULANG PELANGGAN PASAR UMUM UBUD
}

\author{
Putri Anggreni \\ Fakultas Ekonomi, Universitas Mahendradatta Denpasar \\ e-mail: gekcay@gmail.com
}

\begin{abstract}
As the foundation of economic and micro enterprises, traditional markets are increasingly replaced by modern market that intensively rushed into the countryside. To be competitive, small businesses in the traditional market needs to learn the management of marketing and consumer behavior, in the hope that customers will remain loyal to the product offered. The purpose of this study is to analyze the effect of perceived value toward customer's satisfaction and repeat buying intention at the Ubud Traditional Market. The data have been analyzed by using Structural Equation Modeling (SEM) with the aid of a computer program Analysis of Moment Structure (AMOS). Sampling was taken by non-probability sampling, especially using the purposive and convenience sampling techniques. The study was conducted in December 2013 up to July 2014 involved for about 152 respondents. The results showed that the influence of perceived value to customer's satisfaction is positive with a coefficient of 0.382 , the effect of perceived value toward customer's repeat buying intention is also positive with a coefficient of 0.129 , and the influence of customer's satisfaction toward customers repeat buying intention is positive as well, with a coefficient of 0.620. With these results, management was advised to have a better understanding of consumer behavior, customer's satisfaction, and customer buying intention in traditional market.
\end{abstract}

Keywords: perceived value, satisfaction, repeat buying intention, traditional market

\section{PENDAHULUAN}

Keberadaan pasar tradisional yang menjadi tumpuan ekonomi rakyat kelas bawah dan pelaku usaha mikro kian tergusur. Sementara pasar moderen kian menjamur bahkan hingga ke pedesaan. Bank Pembangunan Asia (ADB) memperkirakan jumlah pasar tradisional menurun sebesar 8,1 persen sepanjang 2011. Berbanding terbalik dengan pasar modern yang tumbuh 31,4 persen pada periode yang sama.

Masyarakat cenderung meninggalkan pasar tradisional karena pasar modern memiliki keunggulan-keunggulan seperti: jarak yang relatif dekat, suasana belanja yang lebih bersih dan nyaman. Hasil survei menunjukkan meski jumlah pasar tradisonal di Indonesia mencapai 1,7 juta unit atau mengambil porsi 73 persen dari keseluruhan pasar yang ada, namun laju pertumbuhan pasar modern ternyata jauh lebih tinggi dibandingkan dengan pasar tradisonal. Yang tergolong ke dalam pasar modern ini adalah hypermarket, supermarket, minimarket, dan departmen store. Pertumbuhan pasar tradisional hanya mencapai 5 persen per tahun. Sedangkan pasar modern mencapai 16 persen. Secara lebih rinci disebutkan bahwa minimarket mempunyai pangsa pasar sebesar 5 persen dengan laju pertumbuhan sebesar 15 persen. Pangsa supermarket mencapai 17 persen dengan tingkat pertumbuhan 7 persen. Adapun hypermarket, dengan pangsa 
pasar 5 persen laju pertumbuhaannya mampu melejit hingga 25 persen per tahun. Jadi tingkat pertumbuhan pasar modern rata-rata adalah 16 persen setiap tahunnya (Nielson, 2004).

Pertumbuhan pasar modern dibandingkan dengan pasar tradisional yang pesat terjadi di banyak daerah terjadi pula di Kabupaten Gianyar. Pertumbuhan pasar modern di Kabupaten yang dikenal sebagai kota seni terbilang cukup pesat selama 3 (tiga) tahun terakhir ini. Data jenis pasar di Kabupaten Gianyar disajikan pada tabel 1 di bawah ini.

Tabel 1. Data Jumlah Pasar Tradisional dan Pasar Modern di Kabupaten Gianyar Tahun $2009-2011$

\begin{tabular}{ccccc}
\hline \multirow{2}{*}{ Tahun } & \multicolumn{4}{c}{ Jenis Pasar } \\
\cline { 2 - 5 } & \multicolumn{2}{c}{ Pasar Tradisional } & \multicolumn{2}{c}{ Pasar Modern } \\
\cline { 2 - 5 } & Jumlah & Pertumbuhan (\%) & Jumlah & Pertumbuhan (\%) \\
\hline 2009 & 31 & 0 & 11 & 18,18 \\
2010 & 31 & 0 & 13 & 107,7 \\
2011 & 31 & 0 & Rata-rata & 56,73 \\
\hline \multicolumn{4}{c}{ Rata-rata } & \multicolumn{3}{c}{ Pertumbuhan } \\
\hline
\end{tabular}

Sumber: Disperindag Kabupaten Gianyar, 2011

Tabel 1 menunjukkan bahwa jumlah pasar tradisional dari tahun 2009 sampai dengan 2011 tidak mengalami perubahan. Sedangkan pasar modern jumlah pasar modern yang paling sedikit pada tahun 2009 yaitu sebanyak 11 unit, sedangkan pertumbuhan terendah yaitu tahun 2010 sebesar 18,18 persen. Jumlah pasar modern paling banyak terjadi pada tahun 2011 yaitu sebanyak 27 unit pasar, sedangkan pertumbuhan tertinggi terjadi pada tahun 2011 yaitu sebesar 107,7 persen.

Gambar 1 disajikan perbandingan laju pertumbuhan pasar tradisional dengan laju pasar modern di Kabupaten Gianyar selama kurun waktu 3 (tiga) tahun.

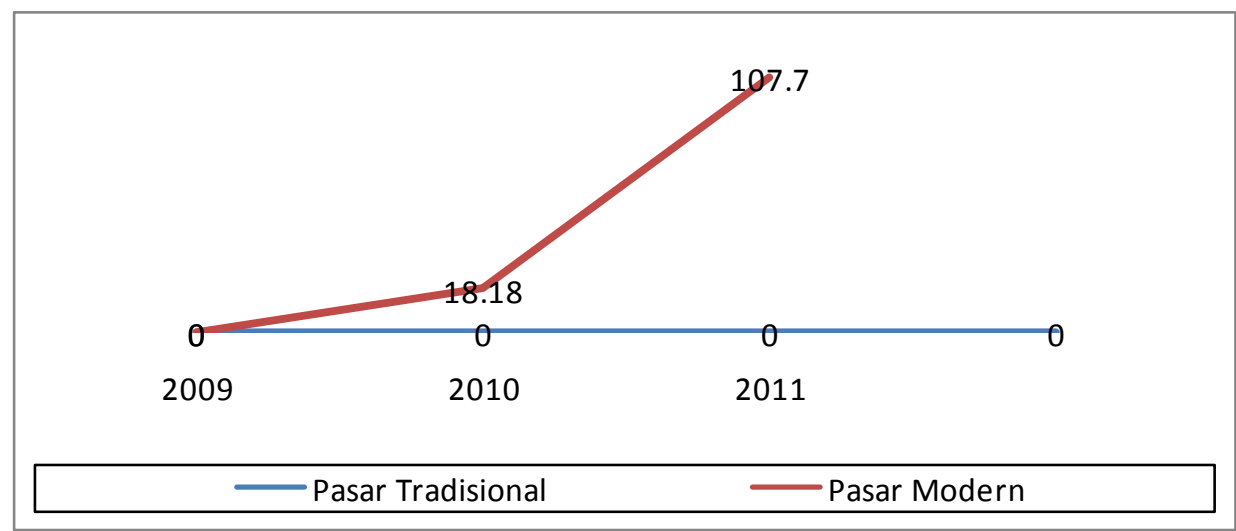

Sumber: Disperindag Kabupaten Gianyar, 2011

Gambar 1. Kurva Pertumbuhan Jumlah Pasar Tradisional dan Pasar Modern di Kabupaten Gianyar Tahun 2009 - 2011

Gambar 1 menunjukkan bahwa terjadi ketimpangan antara pertumbuhan jumlah pasar tradisional dengan jumlah pasar modern di Kabupaten Gianyar. Ketimpangan yang sangat besar terjadi pada tahun 2009 dan 2011. Fenomena yang tergambarkan pada Gambar 1 merupakan 
fenomena yang menarik. Lonjakan yang sangat tinggi pada jumlah pasar modern yang tidak diikuti oleh peningkatan jumlah pasar tradisional mengindikasikan terjadinya pergeseran budaya masyarakat, dimana para pengusaha ritel yang tergolong pasar modern melihat dengan baik peluang usaha ini, hal ini diindikasikan dengan semakin menjamurnya tempat berjualan yang tergolong pasar modern di Kabupaten Gianyar dari tahun 2009 sampai dengan 2011.

Dari pergeseran situasi yang menyebabkan menjamurnya pasar ritel modern tersebut sangatlah penting mempelajari perilaku konsumen bagi pemasar atau pedagang pasar tradisional dengan harapan agar pelanggan setia atau loyal terhadap produk-produk yang ditawarkan. Jika para pemasar memahami perilaku konsumennya, maka mereka akan bisa memprediksi bagaimana konsumen akan bereaksi terhadap berbagai isyarat pemasaran dan isyarat lingkungan sehingga berdasarkan hasil prediksi itu mereka bisa mempertajam strategi pemasaran yang sesuai. Selain itu pemahaman perilaku konsumen juga sangat bermanfaat untuk merancang strategi retensi pelanggan dan kepuasan pelanggan (Suprapti, 2009).

Untuk memberdayakan pasar-pasar tradisional agar tetap bisa bersaing dengan pasar modern di Kabupaten Gianyar, Pemerintah Kabupaten Gianyar pada tahun 2011 secara bertahap menata pasar-pasar tradisional yang berada di Kabupaten Gianyar dengan melakukan perbaikanperbaikan seperti sarana parkir kendaraan dan perbaikan-perbaikan kecil di area pasar, salah satunya adalah Pasar Umum Ubud yang direvitalisasi dan diharapkan untuk meniru manajemen pusat perbelanjaan modern, terutama berkaitan dengan masalah kebersihan sehingga mampu mengatasi kekurangan dan kelemahan pasar tradisional yang identik dengan masalah becek, kotor, bau dan areal parkir yang tidak nyaman bagi pelangganberdasarkan masalah tersebut program revitalisasi Pasar Umum Ubud diharapkan mampu memberikan value yang baik sehingga pelanggan bisa merasa nyaman dan puas dalam berbelanja di pasar tradisional dan berminat untuk melakukan pembelian ulang.

Untuk itu dirasakan perlu adanya pemahaman para pedagang pasar tradisional terhadap persepsi konsumen atas sejumlah manfaat yang akan diterima dibandingkan dengan pengorbanan yang dilakukan terhadap produk yang dijual sehingga mereka bisa bersaing dengan pesaing lainnya seperti pasar ritel-ritel modern yang berdampak pada kepuasan pelanggan. Perilaku konsumen dipengaruhi oleh faktor-faktor internal dan eksternal, artinya baik bahwa perilaku konsumen baik konsumen individu maupun konsumen organisasi, dipengaruhi oleh faktor dalam dirinya serta faktor di luar dirinya atau faktor lingkungan (Suprapti, 2009), salah satu faktor perilaku konsumen adalah perceived value yang berperan serta menentukan kepuasan konsumen, pedagang harus bisa memberikan rasa puas terhadap pelanggan karena dengan memperhatikan kepuasan pelanggan berarti pedagang mempertahankan kesetiaan pelanggan dan mendapatkan pelanggan baru, selain itu mendorong pelanggan kembali datang untuk berbelanja di pasar.

Perceived value berdampak pada kepuasan konsumen. Hume \& Gillian(2008), menyatakan adanya hubungan yang positif antara perceived value dengan minat beli ulang. Perceived value pelanggan akan mempengaruhi keputusan pelanggan dalam melakukan pembelian atau tidak. Penelitian Solvang (2007) yang berjudul Satisfaction, Loyalty, and Repurchase menyatakan bahwa kepuasan berpengaruh sangat kuat terhadap minat beli ulang dibandingkan pengaruh variabel kualitas pelayanan. Kemudian diperkuat dengan hasil penelitian yang dilakukan Muzahid \& Noorjahan (2009) pada bidang telekomunikasi di Bangladesh memperoleh hasil bahwa kepuasan pelanggan mempunyai dampak positif bagi minat beli ulang pelanggan. 
Berdasarkan uraian pada latar belakang, maka dapat dirumuskan tujuan penelitian adalah untuk menganalisis pengaruh perceived value terhadap kepuasan dan minat beli ulang pelanggan di Pasar Umum Ubud.

\section{KAJIAN TEORI}

Pasar tradisonal adalah pasar yang dikelola secara sederhana dengan bentuk fisik tradisional yang menerapkan sistem transaksi tawar menawar secara langsung dimana fungsi utamanya adalah untuk melayani kebutuhan masyarakat baik di desa, kecamatan, dan lainnya. Harga di pasar tradisional ini mempunyai sifat yang tidak pasti, oleh karena itu bisa dilakukan tawar menawar. Bila dilihat dari tingkat kenyamanan, pasar tradisional selama ini cenderung kumuh dengan lokasi yang tidak tertata rapi. Pembeli di pasar tradisional (biasanya kaum ibu) mempunyai perilaku yang senang bertransaksi dengan berkomunikasi/berdialog dalam hal penetapan harga, mencari kualitas barang, memesan barang yang diinginkan, dan perkembangan harga-harga lainnya.

Barang yang dijual di pasar tradisional umumnya barang-barang lokal dan ditinjau dari segi kualitas dan kuantitas, barang yang dijual di pasar tradisional dapat terjadi tanpa melalui penyortiran yang kurang ketat. Dari segi kuantitas, jumlah barang yang disediakan tidak terlalu banyak sehingga apabila ada barang yang dicari tidak ditemukan di satu kios tertentu, maka dapat dicari ke kios lain. Rantai distribusi pada pasar tradisional terdiri dari produsen, distributor, sub distributor, pengecer, konsumen. Kendala yang dihadapi pada pasar tradisional antara lain sistem pembayaran ke distributor atau sub distributor dilakukan dengan tunai, penjual tidak dapat melakukan promosi atau memberikan discount komoditas. Mereka hanya bisa menurunkan harga barang yang kurang diminati konsumen. Selain itu, dapat mengalami kesulitan dalam memenuhi kontinyuitas barang, lemah dalam penguasaan teknologi dan manejemen sehingga melemahkan daya saing.

Pasar tradisional merupakan tempat bertemunya penjual dan pembeli serta ditandai dengan adanya transaksi penjual pembeli secara langsung dan biasanya ada proses tawarmenawar, bangunan biasanya terdiri dari kios-kios atau gerai, los dan dasaran terbuka yang dibuka oleh penjual maupun suatu pengelola pasar. Kebanyakan menjual kebutuhan sehari-hari seperti bahan-bahan makanan berupa ikan, buah, sayur-sayuran, telur, daging, kain, pakaian barang elektronik, jasa dan lain-lain. Selain itu, ada pula yang menjual kue-kue dan barangbarang lainnya. Pasar seperti ini masih banyak ditemukan di Indonesia, dan umumnya terletak dekat kawasan perumahan agar memudahkan pembeli untuk mencapai pasar Pasar tradisional adalah pasar yang dibangun dan dikelola oleh Pemerintah Daerah, Swasta, Badan Usaha Milik Negara dan Badan Usaha Milik Daerah, termasuk kerjasama swasta dengan tempat usaha berupa toko, kios, los dan tenda yang dimiliki/dikelola oleh pedagang kecil, menengah, swadaya masyarakat atau koperasi dengan usaha skala kecil, modal kecil dan dengan proses jual beli barang dagangan melalui tawar-menawar. Isu utama yang berkaitan dengan perkembangan pasar tradisional adalah sebagai berikut.

1. Jarak antara pasar tradisional dengan hypermarket yang saling berdekatan.

2. Tumbuh pesatnya minimarket (yang dimiliki pengelola jaringan) ke wilayah pemukiman.

3. Penerapan berbagai macam syarat perdagangan oleh ritel modern yang memberatkan pemasok barang.

4. Kondisi pasar tradisional secara fisik sangat tertinggal, maka perlu ada program kebijakan untuk melakukan pengaturan. 
Untuk mengatasi berbagai permasalahan tersebut, dikembangkan berbagai upaya untuk mengembangkan pasar tradisional. Salah satunya dilakukan dengan pemberdayaan pasar tradisional, antara lain dengan mengupayakan sumber-sumber alternatif pendanaan untuk pemberdayaan, meningkatkan kompetensi pedagang dan pengelola, memprioritaskan kesempatan memperoleh tempat usaha bagi pedagang pasar tradisional yang telah ada sebelum dilakukan renovasi atau relokasi, serta mengevaluasi pengelolaan.

Sebagian konsumen pasar tradisional adalah masyarakat kelas menengah ke bawah yang memiliki karakteristik sangat sensitif terhadap harga. Ketika faktor harga rendah yang sebelumnya menjadi keunggulan pasar tradisional mampu diruntuhkan oleh pasar modern, secara relatif tidak ada alasan konsumen dari kalangan menengah ke bawah untuk tidak turut berbelanja ke pasar modern dan meninggalkan pasar tradisional.

Pasar modern adalah pasar yang dikelola dengan manajemen modern, umumnya terdapat di perkotaan, sebagai penyedia barang dan jasa dengan mutu dan pelayanan yang baik kepada konsumen yang pada umumnya anggota masyarakat kelas menengah ke atas. Pasar modern antara lain mall, supermarket, department store, shopping centre, waralaba, toko mini swalayan, pasar serba ada, toko serba ada dan sebagainya.

Barang yang dijual di sini memiliki variasi jenis yang beragam. Selain menyediakan barang lokal, pasar modern juga menyediakan barang impor. Barang yang dijual mempunyai kualitas yang relatif lebih terjamin karena melalui penyeleksian yang ketat sehingga barang yang tidak memenuhi persyaratan klasifikasi akan ditolak. Dari segi kuantitas, pasar modern umumnya mempunyai persediaan barang di gudang yang terukur. Dari segi harga, pasar modern memiliki label harga yang pasti. Pasar modern juga mmberikan pelayanan yang baik dengan adanya pendingin udara yang sejuk, suasana nyaman dan bersih, display barang per kategori mudah dicapai dan relatif lengkap, informasi produk tersedia melalui mesin pembaca, adanya keranjang belanja atau keranjang dorong serta ditunjang adanya kasir dan pramuniaga yang bekerja secara profesional. Rantai distribusi pada pasar ini adalah produsen - distributor pengecer/konsumen.

Dalam pasar modern penjual dan pembeli tidak bertransaksi secara langsung. Pembeli melihat label harga yang tercantum dalam barcode, berada dalam bangunan dan pelayanannya dilakukan secara mandiri (swalayan) atau dilayani oleh pramuniaga. Barang-barang yang dijual, selain bahan makanan seperti: buah, sayuran, daging, sebagian besar barang lainnya yang dijual adalah barang yang dapat bertahan lama. Contoh dari pasar modern adalah pasar swalayan, hypermart, supermarket, dan minimarket.

Pusat perbelanjaan modern merupakan pesaing dan akan mengancam keberadaan pedagang di pasar tradisional. Jika dahulu pusat perbelanjaan lebih banyak ditujukan untuk penduduk berpendapatan menengah ke atas. Kini mereka mulai masuk juga ke kelas menengah ke bawah. Para pengecer kini juga bervariasi memasuki berbagai segmen pasar. Namun, pada masa ini kondisi pasar tradisional mulai memprihatinkan. Dengan kondisi pasar tradisional yang becek, kotor, bau dengan sampah yang menggunung menjadikan pasar itu kian dijauhi. Ini tentu jauh berbeda dengan pasar modern yang tentu lebih dingin, bersih, dan nyaman sehingga konsumen yang dulunya berbelanja kebutuhan sehari-hari di pasar-pasar tradisional maka cenderung berbelanja di supermarket dan jenis pasar modern lainnya.

Pelanggan dalam berbelanja akan meninjau penawaran yang akan memberi nilai tertinggi, dalam hal ini para pelanggan menginginkan nilai maksimal dengan dibatasi oleh biaya 
pencarian serta pengetahuan, mobilitas, dan penghasilan mereka terbatas, mereka berharap akan suatu nilai dan bertindak sesuai dengan hal tersebut. Nilai yang dirasakan (perceived value) merupakan akibat atau keuntungan-keuntungan yang diterima pelanggan. Customer Perceived Value dibangun dari beberapa elemen, antara lain image pembeli terjadap performansi produk, saluran distribusi, jaminan kualitas, reputasi perusahaan, kepuasan dan penghargaan (Kotler, 2008). Roig, et.al (2006) mendefinisikannya nilai yang dirasakan pelanggan sebagai konstruksi yang dibentuk oleh dua bagian, salah satu manfaat yang diterima (ekonomi, sosial dan relasional) dan lainnya dari pengorbanan yang dibuat (harga, waktu, tenaga, risiko dan kenyamanan) oleh pelanggan.

Menurut Kotler (2008) ada 3 (tiga) cara sebuah perusahaan yang ingin mengembangkan penawarannya terhadap pasar:

1. Meningkatkan total customer value dengan peningkatan kegunaan produk, pelayanan, personil, dan kesan perusahaan.

2. Mengurangi biaya non moneter yang harus dikeluarkan konsumen dengan mengurangi biaya energi, waktu dan fisik.

3. Mengurangi biaya moneter (harga) produk yang harus dibayarkan Customer Delivered Value ini pada akhirnya akan diterima oleh konsumen dan menjadi apa yang disebut dengan Customer Perceived Value atau nilai produk yang dirasakan konsumen sebagai perbedaan kegunaan dan biaya antara sebuah penawaran dan keseluruhan alternatif yang diterima oleh calon konsumen berdasarkan hasil dari sebuah proses evaluasi.

Lebih lanjut, Kotler (2008) beranggapan bahwa nilai produk yang dirasakan ini terdiri dari beberapa hal yaitu:

1. Performa produk, termasuk di dalamnya adalah variasi cakupan produk, harga, fitur, merk, kemasan/ukuran, garansi dan pengambilan.

2. Saluran distribusi, termasuk di dalamnya misalnya adalah cakupan wilayah, lokasi, akses, waktu antrian, kenyamanan tempat penjualan dan pelayanan.

3. Jaminan kualitas, termasuk di dalamnya misalnya adalah terpenuhinya tujuan konsumen mengkonsumsi produk atas dasar kualitas yang diterima, frekuensi terjadinya penyimpangan kualitas dan kepuasan konsumen atas kualitas produk.

4. Reputasi perusahaan, yaitu tingkat kepercayaan konsumen terhadap reputasi perusahaan.

Secara singkat, Kotler (2008) telah mendefinisikan "satisfaction is a persons feeling of pleasure or disappointment resulting from comparing a product's perceived performance (or outcome) in relation to his or her expectation". Definisi ini menjelaskan bahwa kepuasan ialah tingkat perasaan seseorang setelah membandingkan kinerja atau hasil yang dirasakannya dibandingkan dengan harapannya. Jadi tingkat kepuasan merupakan fungsi perbedaan antara kinerja yang dirasakan dengan harapan.

Boone \& Kurtz (2007) mengartikan kepuasan pelanggan sebagai hasil dari barang atau jasa yang memenuhi atau melebihi kebutuhan dan harapan pembeli. Konsep dari barang atau jasa yang memberikan kepuasan pembeli karena bisa memenuhi dan melebihi harapan-harapan mereka adalah hal yang sangat penting dalam organisasi usaha, sebuah organisasi usaha yang gagal untuk memenuhi kepuasan pelanggan dibandingkan dengan pesaingnya tidak akan bisa bertahan dalam waktu yang lama.

Minat beli ulang adalah proses berulang yang dilakukan pelanggan dalam membeli barang atau jasa dari toko tertentu dimana alasan utama dalam minat beli ulang adalah pengalaman pelanggan setelah berbelanja. Dengan melakukan pembelian secara berulangkali terhadap satu 
atau lebih merk tersebut memuaskan maka kemungkinan besar pembeli akan menunjukkan suatu kegiatan pembelian rutin yang mana dalam kegiatan pembelian selanjutnya akan terstruktur lebih baik, sehingga mendorong cepatnya proses pengambilan keputusan membeli.

Menurut Bigne, et.al (2008), minat dalam berperilaku dibagi menjadi 2 (dua) bagian yaitu return (keinginan dari pelanggan untuk menggunakan layanan yang diberikan provider) dan recommend (keinginan pelanggan untuk memberikan rekomendasi pada pihak lain untuk mencoba layanan yang pernah dialaminya).

Konsep penelitan yang disusun pada Gambar 2 menggambarkan bahwa variabel kepuasan pelanggan (Y1) dan variabel minat beli ulang pelanggan (Y2) dipengaruhi langsung oleh variabel perceived value $(\mathrm{X})$.

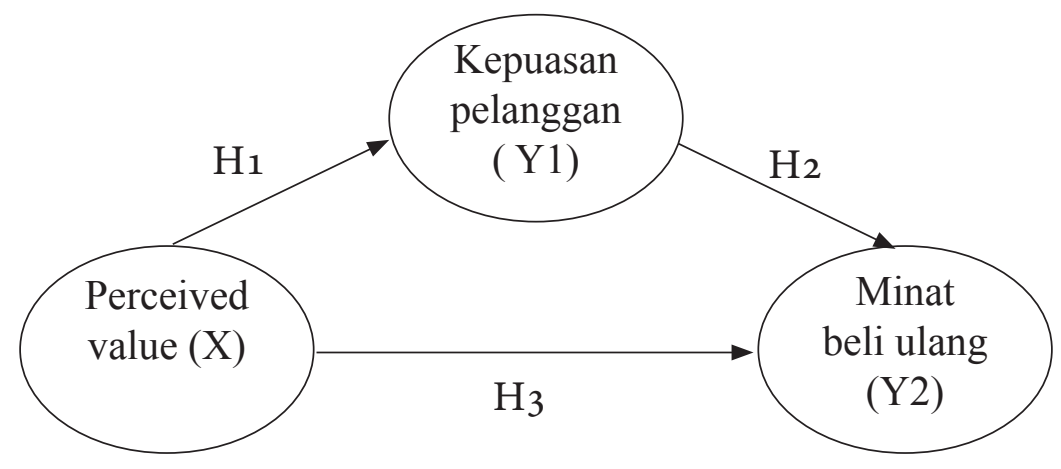

Gambar 2. Kerangka Pemikiran

Perumusan Hipotesa adalah sebagai berikut:

1. Pengaruh perceived value memiliki dampak yang positif dan signifikan terhadap kepuasan pelanggan.

2. Pengaruh perceived value memiliki dampak yang positif dan signifikan terhadap minat beli ulang pelanggan.

3. Pengaruh kepuasan pelanggan memiliki dampak yang positif dan signifikan terhadap minat beli ulang.

\section{METODE PENELITIAN}

\section{Jenis Penelitian}

Penelitian ini merupakan studi penjelasan (explanatory research) yang menjelaskan suatu hubungan antara variabel-variabel melalui pengujian hipotesis (Ghozali, 2011). Jenis penelitian ini dipilih karena tujuan dari penelitian adalah usaha menjelaskan hubungan yang terjadi antar variabel dengan menggunakan kuesioner sebagai alat pengumpul data primer.

Penelitian ini menggunakan SEM (Structural Equation Model) yang didasarkan pada evaluasi atas adanya hubungan saling ketergantungan antar variabel. Menurut Sugiyono (2011) SEM dapat dideskripsikan sebagai suatu analisis yang menggabungkan pendekatan analisis faktor (factor analysis), model struktural (structural model), dan analisis jalur (path analysis). Lebih lanjut dalam Sugiyono (2011) menyatakan bahwa SEM dapat melakukan tiga macam kegiatan secara serentak, yaitu pengecekan validitas dan reliabilitas instrumen (berkaitan dengan analisis faktor konfirmatori), pengujian model hubungan antar variabel (berkaitan dengan analisis jalur), dan kegiatan untuk mendapatkan suatu model yang cocok untuk prediksi (berkaitan dengan analisis regresi atau analisis model struktural). 
Menurut Santoso (2007) secara singkat dapat dijelaskan, bahwa aplikasi permodelan SEM dapat ditempuh dengan terlebih dahulu mengikuti tahapan measurement model dan structural model. Kedua model tersebut secara berturut-turut dimaksudkan untuk mengkonfirmasi dimensi yang dikembangkan pada sebuah faktor dan untuk mengetahui struktur hubungan yang membentuk atau menjelaskan kausalitas antara faktor.

Prosedur SEM dapat dilakukan dengan 2 (dua) cara: melalui hubungan kausalitas yang dipersentasikan oleh serangkaian persamaan struktural (misalnya regresi), dan hubungan struktural ini dapat dibuat dalam bentuk model gambar agar diperoleh konseptualisasi yang lebih jelas atas persoalan yang diteliti.

Penekanan kasus dalam penelitian ini ditujukan pada atribut atau indikator dari variabel perceived value yang mempengaruhi kepuasan pelanggan yang pada akhirnya berdampak kepada minat beli ulang secara langsung.

\section{Identifikasi Variabel Penelitian}

Berdasarkan masalah dan hipotesis yang diajukan, serta berkaitan dengan kajian empiris dan teoritis, maka konstruk-konstruk yang diteliti adalah konstruk yang berkaitan dengan perceived value, kepuasan pelanggan dan minat beli ulang. Variabel tersebut dapat dikelompokan menjadi variabel eksogen dan variabel endogen. Variabel eksogen adalah perceived value (X) sedangkan untuk variabel endogen adalah kepuasan pelanggan (Y1) dan minat beli ulang (Y2). Masing-masing variabel terdiri atas beberapa dimensi dan atau indikator.

\section{Operasional Variabel Penelitian}

Definisi menurut Sugiyono (2011) adalah definisi yang dibuat secara spesifik sesuai dengan kriteria pengujian atau pengukuran. Tujuannya adalah agar pembaca lain juga memiliki pengertian yang sama. Definisi operasional dibentuk dengan cara mencari indicator empiris konsep. Definisi variabel-variabel dapat didefinisikan sebagai berikut.

\section{Perceived Value}

Perceived Value adalah nilai yang dirasakan oleh pelanggan akibat dari keuntungankeuntungan yang diterima pelanggan.

2. Kepuasan pelanggan (Customer Satisfaction) adalah tingkat perasaan konsumen setelah membandingkan antara apa yang dia terima dan harapannya.

3. Minat Beli Ulang/Repurchase Intention adalah pernyataan seseorang yang mencerminkan rencana untuk membeli kembali produk-produk dalam suatu periode waktu tertentu.

\section{Pengukuran Variabel}

Skala pengukuran yang digunakan dalam penelitian ini adalah skala Likert. Skala Likert adalah skala yang dapat digunakan untuk mengukur sikap, pendapat, dan persepsi seseorang tentang suatu objek atau fenomena tertentu (Siregar, 2010). Lebih lanjut dalam Siregar (2010) skala Likert memiliki dua bentuk pernyataan, yaitu pernyataan positif dan negatif. Pernyataan positif diberi skor 5, 4, 3, 2, 1 sedangkan pernyataan negatif diberi skor 1, 2, 3, 4, 5. Pernyataan yang digunakan dalam penelitian ini adalah bentuk pernyataan positif. Bentuk jawaban Likert pada pernyataan positif terdiri atas (4) Sangat Setuju, (3) Setuju, (2) Tidak Setuju dan (1) Sangat tidak Setuju. Pada penelitian ini menggunakan skala Likert 4 poin untuk menghasilkan (pilihan paksaan), dimana dengan skala 4 point tidak ada pernyataan ragu-ragu atau netral sehingga jawaban responden akan mengarah ke positif atau negatif semakin jelas. 


\section{Populasi Dan Sampel}

Populasi merupakan kumpulan dari individu-individu dengan kualitas serta ciri-ciri yang telah ditetapkan. Menurut Sugiyono (2011) populasi merupakan wilayah generalisasi yang terdiri atas obyek atau subyek yang mempunyai kualitas dan karakteristik tertentu yang ditetapkan oleh peneliti untuk dipelajari dan kemudian ditarik kesimpulannya. Dalam penelitian ini populasi adalah seluruh pengunjung Pasar Umum Ubud.

Sampel adalah suatu prosedur dimana hanya sebagian populasi saja yang diambil dan dipergunakan untuk menentukan sifat serta ciri yang dikehendaki dari suatu populasi (Siregar, 2010). Sugiyono (2011) menyarankan bahwa ukuran sampel terbaik untuk penelitian multivariate adalah 5-10 observasi untuk setiap parameter yang diestimasi. Penelitian ini terdapat 15 (lima belas) indikator, sehingga jumlah sampel yang ditetapkan adalah 10 observasi setiap indikator, sehingga totalnya adalah 150 responden. Alasan memilih 10 observasi setiap parameter adalah karena kemudahan memperoleh responden, dengan asumsi mudah menemukan responden yang sesuai kriteria yang ditetapkan, keterbatasan tenaga, waktu, dan biaya, selain itu pula ukuran sampel sebaiknya dipenuhi dalam teknik analisis SEM adalah minimum berjumlah 100 dan maksimum 200.

\section{Teknik Pengambilan Sampel}

Pemilihan teknik sampling, yaitu upaya peneliti untuk mendapatkan sampel yang resperentatif yang dapat menggambarkan populasi. Pengambilan sampel dilakukan dengan metode sampel non probability sampling, yaitu setiap unsur dalam populasi tidak memiliki kesempatan atau peluang yang sama untuk dipilih sebagai sampel, bahkan probabilitas anggota tertentu untuk dipilih tidak diketahui (Siregar, 2010). Teknik sampel non probability sampling yang digunakan adalah purposive sampling dan conveince sampling. Purposive sampling merupakan metode penetapan responden untuk dijadikan sampel berdasarkan pada kriteria-kriteria tertentu, dalam hal ini responden adalah pengunjung Pasar Umum Ubud yang mengunjungi serta berbelanja minimal tiga kali dalam sebulan terakhir dan mengetahui bacaan dan mampu menulis. Convenience sampling adalah teknik penentuan sampel berdasarkan kebetulan saja, anggota populasi yang ditemui peneliti dan bersedia menjadi responden untuk dijadikan sampel atau peneliti memilih orang-orang yang terdekat.

\section{Metode Pengumpulan Data}

Pengumpulan data dilakukan melalui survey dengan cara membagikan kuesioner kepada responden yang telah memenuhi kriteria sesuai dengan kriteria yang diinginkan. Kuesioner disebarkan di Pasar Umum Ubud untuk menemukan responden yang sesuai dengan kriteria yang ditetapkan. Kuesioner disebarkan hingga didapatkan responden sesuai dengan ukuran sampel penelitian yang telah ditetapkan sebelumnya.

\section{Teknik Analisa Data}

Validitas digunakan untuk menguji sejauh mana ketepatan dan kecermatan suatu alat ukur melakukan ukurannya. Menurut Maholtra (2005), instrumen pengukuran dapat dikatakan mempunyai validitas yang tinggi apabila alat tersebut memberikan hasil ukur yang sesuai dengan yang dimaksud dilakukan dengan pengukuran tersebut. Pengukuran validitas dilakukan secara statistik dengan hasil perhitungan analisis faktor yang menggambarkan seberapa kuat butirbutir instrumen (variabel terukur) menyatu satu sama lainnya. Artinya butir-butir pertanyaan tersebut koheren atau bersumber dari konsep yang sama. Batas minimal validitas instrumen ditentukan berdasarkan nilai-nilai kritis koefisien korelasi $(r)$ product moment, suatu instrumen 
penelitian dilakukan valid apabila koefisien korelasinya antar butir lebih besar dari 0,30 dengan tingkat kesalahan alpha 0,05 (Sugiyono, 2014).

Uji reliabilitas dilakukan untuk menguji konsistensi suatu instrumen didalam mengukur gejala yang sama. Uji reliabilitas mampu menunjukan sejauh mana instrumen dapat dipercaya atau dapat diandalkan. Menurut Umar (2002), yang dipergunakan untuk penetapan butir-butir instrumen yang andal yaitu: Koefisien Alpha Cronbach 0,70-0,80 maka reliabilitasnya bagus.

Alat analisis yang digunakan dalam penelitian ini adalah Structural Equation Modelling (SEM) dengan bantuan program komputer Analysis of Moment Structure (AMOS).

Menurut Ghozali (2008), langkah-langkah penyusunan mode penelitian seperti yang ditentukan dalam aturan SEM diterapkan sebagai berikut:

Hubungan yang dihipotesiskan antar variabel latent ditentukan dengan justifikasi teoritis yang kuat. Tahap pengembangan model berfokus pada model structural, dan mempresentasikan kerangka teoritis untuk diuji.

1. Penyusunan Diagram Alur

Pengembangan teori dilanjutkan dengan ilustrasi konsep melalui diagram alur (path diagram). Path Diagram dapat mengurangi kemungkinan specification error dengan menyoroti hubungan-hubungan yang dihilangkan, serta variabel-variabel yang dikeluarkan. Path diagram juga membantu dalam deteksi kesalahan dalam persamaan yang telah dibentuk. Path diagram dapat dilihat pada Gambar 3.

Alur menggambarkan kerangka penelitiaan dalam sebuah diagram alur (path diagram):

1.1 Anak panah satu arah digunakan untuk melambangkan hubungan kausalitas.

1.2 Bentuk elips, digunakan untuk melambangkan suatu konstruk yang tidak diukur dengan menggunakan satu atau lebih indikator.

1.3 Bentuk kotak, melambangkan variabel yang diukur langsung (observerb).

1.4 Hurufe, digunakan untuk melambangkankesalahan apada masing-masing pengamatan. Nilai ini harus diberikan kepada setiap variabel observerb.

1.5 Variabel eksogen, adalah variabel yang mempengaruhi, disebut variabel independen dalam analisis regresi. Variabel endogen, adalah variabel yang dipengaruhi, disebut variabel dependen dalam analisis regresi. 


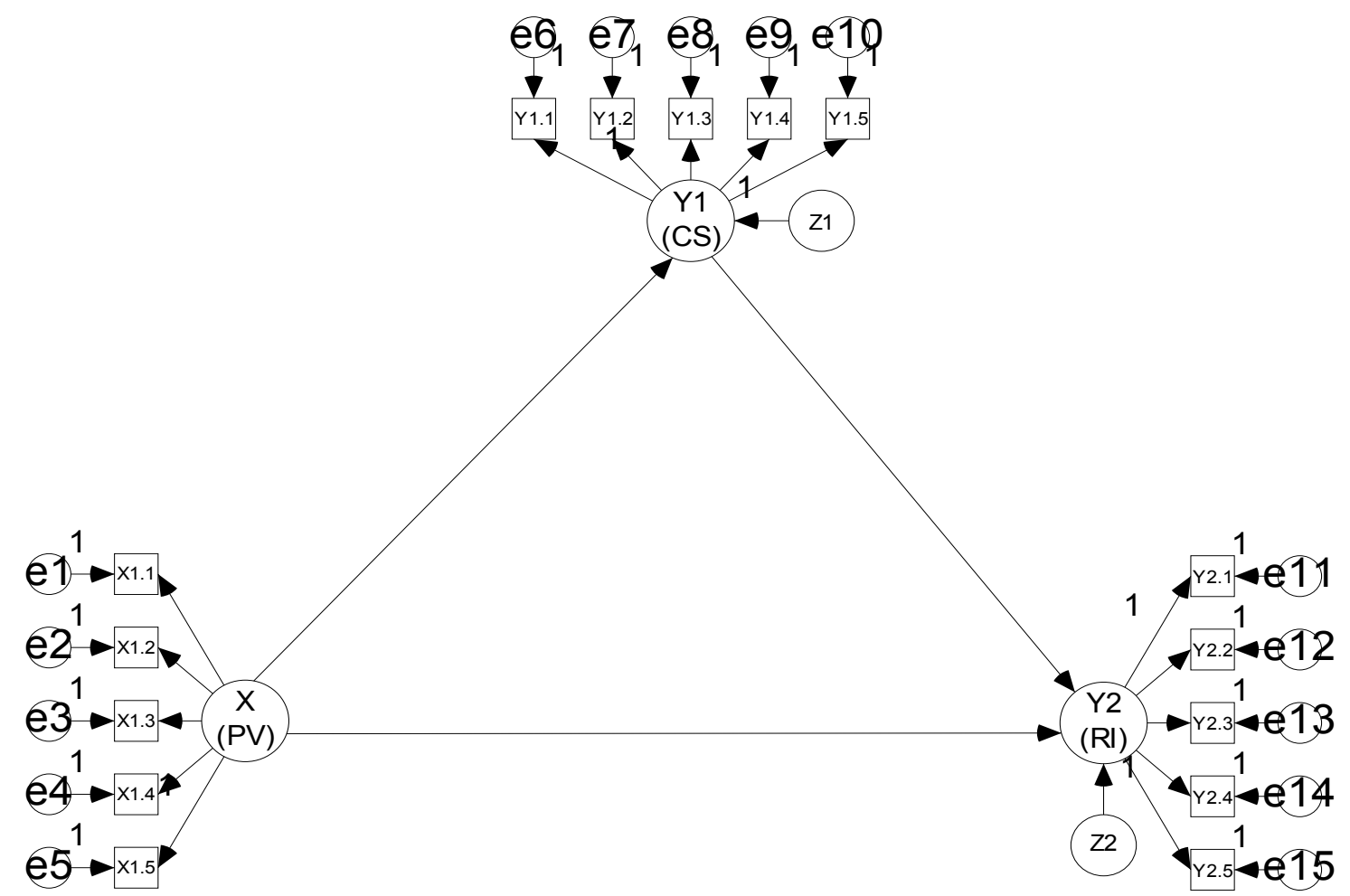

Gambar 3. Model jalur Hubungan Konstruk Perceived Value (PV), Kepuasan atau Customer Satisfaction (CS), dan Minat Beli Ulang Pelanggan atau Repurchase Intention (RI).

2. Memilih Matriks Input

Jenis matrik input yang dimasukkan adalah data input berupa matrik varian atau kovarian atau matrik korelasi. Langkah berikutnya adalah dengan melakukan estimasi model pengukuran dan estimasi struktur persamaan.

2.1 Estimasi Model pengukuran (Measurement Model). Juga sering disebut dengan Confirmatory Factor Analysis (CFA). Yaitu dengan menghitung diagram model penelitian dengan memberikan anak panah dua arah antara masing-masing konstruk. Langkah ini adalah untuk melihat apakah matriks kovarian sampel yang diteliti mempunyai perbedaan yang signifikan atau tidak dengan matrik populasi yang diestimasi. Diharapkan tidak terdapat perbedaan yang signifikan sehingga nilai signifikansi pada Chi-Square di atas 0,05.

2.2 Model Struktur Pemasaran (Structure Equation Model). Juga sering disebut Full Model, yaitu melakuakan running program dengan model penelitian. Langkah ini untuk melihat berbagai asumsi yang diperlukan, sekaligus melihat apakah perlu dilakukan modifikasi atau tidak dan pada akhirnya adalah menguji hipotesis penelitian.

3. Identifikasi Model

Informasi yang diperoleh dari data diuji untuk menentukan apakah cukup untuk mengestimasi parameter dalam model. Nilai yang unik untuk seluruh parameter yang diperoleh. Identifikasi yang sering muncul sehingga model tidak layak diantaranya adalah sebagai berikut:

3.1 Standard error yang besar untuk satu atau beberapa koefisien. Standard error yang besar menunjukan adanya ketidaklayakan model yang disusun. Standard error yang diharapkan adalah relatif kecil, yaitu di bawah 0,5 atau 0,4 akan tetapi nilai standard error tidak boleh negatif yang akan diuraikan lebih lanjut di bawah pada poin 3 . 
3.2 Program tidak mampu menghasilkan matriks informasi yang seharusnya disajikan. Jika program tidak mampu menghasilkan suatu solusi yang unik, maka output tidak akan keluar. Hal ini bias disebabkan oleh beberapa hal, misalnya sampel terlalu sedikit.

3.3 Adanya varians error yang negatif. Varians error yang diharapkan adalah relatif kecil tetapi tidak boleh negatif. Jika nilainya negatif maka sering disebut Heywood case dan model tidak boleh diinterpresentasikan dan akan muncul pesan pada output berupa this solution is not admissible.

3.4 Munculnya korelasi yang sangat tinggi antar koefisien estimasi yang didapat (misal $\geq 0,9$ ). Gangguan ini juga sering disebut sebagai singularitas dan menjadikan model tidak layak untuk digunakan sebagai sarana untuk mengkonfirmasikan suatu teori yang telah disusun.

4. Estimasi parameter

Setelah model struktural dapat diidentifikasi, maka estimasi parameter dapat diketahui. Pada tahap ini, estimasi parameter untuk suatu model diperoleh dari data karena program AMOS akan menghasilkan matriks kovarians berdasarkan model (model based covariance matrix) yang sesuai dengan kovarian matriks sesungguhnya (observed covariance matrix). Uji signifikansi dilakukan dengan menentukan apakah parameter yang dihasilkan secara signifikan berbeda dari nol.

5. Penilaian model fit

Uji Kesesuaian dan Uji Statistik. Adanya beberapa uji kesesuaian statistik, berikut adalah beberapa kriteria yang lazim dipergunakan.

5.1 Likelihood ratio chi-square statistic $(\chi 2)$. Pada program AMOS, nilai Chi Square dimunculkan dengan perintah Icmin. Nilai yang diharapkan adalah kecil, atau lebih kecil dari chi-square yang signifikan (kurang dari 0,05) menunjukan bahawa data empiris yang diperoleh memiliki perbedaan dengan teori yang telah dibangun berdasarkan structural equation modeling.

5.2 Probabilitas. Dimunculkan dengan menu $\backslash$ p. Diharapkan nilai probabilitas lebih dari $0,05(5 \%)$.

5.3 Root Mean Square Error Approximantion (RMSEA). Dimunculkan dengan perintah rmsea. Nilai yang diharapkan adalah kurang dri 0,08.

5.4 Goodness of Fit Index (GFI). Dimunculkan dengan perintah gfi dan nilai yang diharapkan adalah lebih besar dari 0,9.

5.5 Adjust Goodness of Fit Index (AGFI). Dimunculkan dengan perintah agfi dan nilai yang diharapkan adalah lebih besar dari 0,9.

5.6 The Minimum Sampel Discrepancy Function atau Degree of Freedom (CMIN/DF). Dimunculkan dengan perintah cmin dan nilai yang diharapkan adalah lebih kecil dari 2 atau 3.

5.7 Tucker Lewis Index (TLI). Dimunculkan dengan perintah tli dan nilai yang diharapkan adalah lebih besar dari 0,95.

5.8 Comarative Fit Index (CFI). Dimunculkan dengan perintah cfi dan nilai yang diharapkan adalah lebih besar dari 0,95.

6. Modifikasi Model

Modifikasi model akan diperlukan jika hasil pada tahap keenam tidak fit. Modifikasi model untuk memperbaiki model yang telah disusun harus didukung oleh justifikasi teori yang kuat. Penentuan Chi-Square antara model sebelum modifikasi dengan model setelah modifikasi diharapkan lebih dari 3,84. 
7. Validasi silang model

Validasi silang penting untuk modifikasi substantial yang dilakukan terhadap model asli yang dilakukan pada langkah di atas.

\section{Lokasi Dan Jadwal Penelitian}

Penelitian ini dilakukan di Pasar Umum Ubud, Kecamatan Ubud Kabupaten Gianyar. Lokasi penelitian ini dipilih karena Pasar Umum Ubud merupakan salah satu pasar tradisional yang berada di Kabupaten Gianyar yang direvitalisasi dan diharapkan mampu memberikan pelayanan yang baik terhadap konsumen. Sedangkan objek penelitian dalam penelitian ini adalah pengaruh perceived value terhadap kepuasan dan minat beli ulang pelanggan di Pasar Umum Ubud. Jadwal Penelitian dalam penelitian ini adalah awal bulan Desember 2013 sampai dengan Juli 2014.

\section{HASIL DAN PEMBAHASAN}

Penelitian ini dilakukan dengan menyebarkan kuesioner kepada responden yang telah disesuaikan dengan kriteria sampel. Kuesioner disebar sebanyak kepada 160 responden, tetapi oleh karena terdapat 8 responden yang tidak mengisi data kuesioner dengan lengkap, maka data yang siap untuk diolah hanya berasal dari 152 responden. Namun, data tersebut telah cukup untuk digunakan sebagai sumber data olah pada penelitian ini karena telah memenuhi syarat jumlah sampel yaitu antara 100-200 data.

Berdasarkan deskripsi karakteristik data responden dirangkum ke dalam tabel berikut.

Tabel 2. Data Karakteristik Responden

\begin{tabular}{llcc}
\hline \multicolumn{1}{c}{ Karakteristik } & \multicolumn{1}{c}{ Keterangan } & Jumlah & Persentase (\%) \\
\hline Jenis Kelamin & Laki-laki & 99 & 65,13 \\
& Perempuan & 53 & 34,87 \\
\cline { 2 - 4 } Pendidikan & Jumlah & 152 & 100 \\
\cline { 2 - 4 } & SMA & 135 & 88,82 \\
& Diploma & 16 & 10,53 \\
\multirow{5}{*}{ Pekerjaan } & Magister & 1 & 0,66 \\
\cline { 2 - 4 } & Jumlah & 152 & 100 \\
\cline { 2 - 4 } & Mahasiswa & 13 & 8,55 \\
& Pegawai Negeri & 62 & 40,79 \\
& Pegawai Swasta & 16 & 10,53 \\
& Wiraswasta & 61 & 40,13 \\
\cline { 2 - 4 } Kunjungan ke Pasar & Jumlah & 152 & 100 \\
\cline { 2 - 4 } & Lebih dari 3x & 152 & 100 \\
\hline
\end{tabular}

Berdasarkan data tabel di atas dari segi jenis kelamin responden lebih banyak laki-laki dibanding perempuan dengan persentase $65,13 \%$ atau sebanyak 99 orang. Pendidikan responden paling banyak dari kalangan SMA, yaitu sekitar $88,82 \%$ atau sebanyak 135 orang. Berdasarkan pekerjaan, terbanyak berasal dari kalangan pegawai negeri dengan persentase sekitar $40,79 \%$ atau 62 orang. Rata-rata responden telah berkunjung ke pasar lebih dari tiga kali. 
Asumsi-asumsi dalam SEM dibagi ke dalam beberapa kriteria, yaitu:

1. Ukuran sampel

Ukuran sampel pada SEM disyaratkan minimal 5-10 kali jumlah indikator. Penelitian ini menggunakan 15 indikator sehingga rata-rata diperlukan 75 sampai 150 sampel. Pada kenyataannya, telah diperoleh 152 sampel sehingga telah dapat memenuhi kriteria sampel yang dipersyaratkan.

2. Normalitas

Nilai koefisien skewness dan kurtosis $\pm 2,58$ dengan tingkat signifikansi 0,01 sehingga data tersebut telah memenuhi kriteria normalitas.

3. Outliers

Outliers data ditentukan dari jarak Mahalanobis hasil output. Penelitian ini menggunakan 15 indikator dengan tingkat $p<0,001$ maka evaluasi data outliers tidak melebihi $\chi^{2}=$ 37,698. Pada lampiran bagian observations farthest from centroid (Mahalanobis distance) diketahui hampir semua data telah memenuhi kriteria, hanya terdapat satu data yang tidak memenuhi yaitu data observasi ke-30 tetapi data tersebut tidak mengganggu hasil output secara keseluruhan sehingga dapat diabaikan.

4. Multikolinearitas

Oleh karena penelitian ini hanya menggunakan satu eksogen atau satu variabel bebas, maka tidak diperlukan gejala multikolinearitas antar variabel eksogen tidak diperlukan.

5. Hasil Uji Validitas dan Reliabilitas

Syarat dari suatu penelitian dianggap valid apabila nilai validitasnya minimal 0,30 . Sedangkan untuk tingkat reliabilitasnya antara 0,50-0,70. Oleh karena penelitian ini hanya melibatkan 3 variabel dengan tingkat independensi yang tinggi, maka data yang ada telah dianggap memenuhi syarat valid dan reliabel walaupun di beberapa variabel masih terdapat data yang yang mengalami tingkat validitas yang kurang. Program AMOS untuk analisis SEM memungkinkan hal tersebut.

Berdasarkan hasil olah data, dapat dirangkum Goodness of Fit pada data yang ada sesuai tabel berikut. Goodness-of-fit diperlukan untuk melihat dapat tidaknya suatu data digunakan sebagai dasar untuk menjustifikasi hipotesis yang telah ditentukan dan untuk mengetahui dapat tidaknya data pada penelitian ini dapat digunakan untuk program AMOS.

Tabel 3. Tabel Goodness Of Fit

\begin{tabular}{llcc}
\hline Goodness of Fit Index & Cut-off Value & Hasil Analisis & Keterangan \\
\hline X$^{2}$ - Chi- Square & Diharapkan nilai lebih kecil & 156,81 & Baik \\
Significance Probability & $\geq 0,05$ & 0,088 & Baik \\
RMSEA & $\leq 0,08$ & 0,073 & Baik \\
GFI & $\geq 0,90$ & 0,887 & Marginal \\
AGFI & $\geq 0,90$ & 0,844 & Marginal \\
TLI & $\geq 0,95$ & 0,968 & Baik \\
CFI & $\geq 0,95$ & 0,978 & Baik \\
\hline
\end{tabular}

Sumber : Hasil Olah Data

Berdasarkan tabel di atas, secara keseluruhan penelitian ini telah memenuhi kriteria goodness-of-fit. Terdapat dua kriteria yang memperoleh keterangan marginal yaitu GFI dengan skor 0,877 dan AGFI dengan skor 0,844 karena data tersebut mendekati cut-off value tapi masih dapat dianggap memenuhi kriteria. 
Pada bagian regression weights diketahui tingkat $p$ value untuk mengetahui signifikan tidaknya hipotesis yang telah ditentukan dengan syarat nilai $p$ value di bawah 0,05 . Pada bagian standardized regression weights diketahui tingkat koefisien estimasi dari tiap hubungan antar variabel, yang apabila menunjukkan angka positif berarti hipotesis terdukung. Rangkuman hasil uji hipotesis data dilihat pada tabel berikut.

Tabel 4. Hubungan Kontstruks

\begin{tabular}{llllll}
\hline Hubungan konstruks & koefisien & $\boldsymbol{p}$ value & Keterangan \\
\hline $\begin{array}{l}\text { Customer } \\
\text { Satisfaction }\end{array}$ & $<--$ & Perceived Value & 0,382 & 0,336 & Hipotesis terdukung \\
\hline $\begin{array}{l}\text { Repurchase } \\
\text { Intention }\end{array}$ & $<--$ & Perceived Value & 0,129 & 0,520 & Hipotesis terdukung \\
\hline $\begin{array}{l}\text { Repurchase } \\
\text { Intention }\end{array}$ & $<--$ & Customer Satisfaction & 0,620 & 0,129 & Hipotesis terdukung \\
\hline
\end{tabular}

Sumber: Hasil Olah Data

Berdasarkan tabel di atas diketahui hipotesis pada nilai yang dirasakan pelanggan berpengaruh positif terhadap kepuasan pelanggan dengan nilai koefisien 0,382. Hipotesis pada nilai yang dirasakan pelanggan berpengaruh positif terhadap minat beli ulang dengan koefisien 0,129 . Hipotesis pada kepuasan pelanggan berpengaruh positif terhadap minat beli ulang dengan koefisien 0,620 . Ketiga hipotesis tidak memiliki tingkat signifikansi yang baik karena secara keseluruhan $p$ value melebihi yang dipersyaratkan yaitu di bawah 0,05 yang berarti hubungan yang terjadi antar variabel adalah lemah. Namun, hal tersebut tidak berpengaruh terhadap kesimpulan hipotesis karena tingkat signifikansi hanya untuk mengetahui kuat tidaknya hubungan yang terjadi antar variabel, bukan menentukan terdukung tidaknya suatu hipotesis.

\section{Pengaruh Nilai yang Dirasakan (Perceived Value) terhadap Kepuasan Pelanggan (Customer Satisfaction)}

Berdasarkan hasil uji hipotesis, diketahui nilai yang dirasakan pelanggan berpengaruh positif terhadap kepuasan pelanggan tetapi pengaruhnya tidak signifikan. Ini berarti bahwa nilai yang dirasakan pelanggan menjadi pertimbangan kepuasan seorang pelangan berbelanja tetapi bukan menjadi faktor utama yang menentukan puas tidaknya seorang pelanggan berbelanja di Pasar Umum Ubud. Hal tersebut mengindikasikan diperlukan adanya upaya-upaya untuk meningkatkan nilai yang dirasakan pelanggan ketika berbelanja di Pasar Umum Ubud untuk dapat meningkatkan kepuasan pelanggan.

\section{Pengaruh Nilai yang Dirasakan (Perceived Value) terhadap Minat Beli Ulang (Repurchase Intention)}

Berdasarkan hasil uji hipotesis, diketahui nilai yang dirasakan pelanggan berpengaruh positif terhadap minat beli ulang tetapi pengaruhnya tidak signifikan. Ini berarti bahwa nilai yang dirasakan pelanggan menjadi pertimbangan minat seorang pelanggan untuk berbelanja kembali tetapi bukan menjadi faktor utama yang menentukan seorang pelanggan memiliki minat yang kuat untuk berbelanja kembali di Pasar Umum Ubud. Hal tersebut mengindikasikan diperlukan adanya upaya-upaya untuk meningkatkan nilai yang dirasakan pelanggan ketika berbelanja di Pasar Umum Ubud sehingga dapat meningkatkan minat beli ulang pelanggan. 


\section{Pengaruh Kepuasan Pelanggan (Customer Satisfaction) terhadap Minat Beli Ulang (Repurchase Intention)}

Berdasarkan hasil uji hipotesis, diketahui kepuasan pelanggan berpengaruh positif terhadap minat beli ulang tetapi pengaruhnya tidak signifikan. Ini berarti kepuasan pelanggan menjadi pertimbangan minat seorang pelanggan untuk berbelanja kembali tetapi bukan menjadi faktor utama yang menentukan seorang pelanggan memiliki minat yang kuat untuk berbelanja kembali di Pasar Umum Ubud. Hal tersebut mengindikasikan diperlukan adanya upaya-upaya untuk meningkatkan kepuasan pelanggan ketika berbelanja di Pasar Umum Ubud sehingga dapat meningkatkan minat beli ulang pelanggan. Selain itu, kemungkinan terdapat faktor-faktor kepuasan lain di luar dari indikator-indikator yang dijabarkan pada penelitian ini yang dapat meningkatkan minat beli ulang pelanggan.

\section{KESIMPULAN}

Simpulan pada penelitian ini berdasarkan hasil penelitian yang telah dijabarkan pada bagian sebelumnya adalah:

1. Nilai yang dirasakan (perceived value) berpengaruh positif terhadap kepuasan pelanggan (customer satisfaction) di Pasar Umum Ubud. Hal ini berarti nilai yang dirasakan menjadi salah satu faktor yang dipertimbangkan oleh seorang pelanggan untuk menentukan puas tidaknya berbelanja di Pasar Umum Ubud.

2. Nilai yang dirasakan (perceived value) berpengaruh positif terhadap minat beli ulang (repurchase intention) pelanggan di pasar umum Ubud. Hal ini berarti nilai yang dirasakan pelanggan menjadi salah satu faktor yang dipertimbangkan oleh seorang pelanggan untuk menentukan minatnya berbelanja kembali di Pasar Umum Ubud.

3. Kepuasan pelanggan (customer satisfaction) berpengaruh positif terhadap minat beli ulang (repurchase intention). Hal ini berarti kepuasan pelanggan menjadi salah satu faktor yang dipertimbangkan oleh seorang pelanggan untuk menentukan minatnya berbelanja kembali di Pasar Umum Ubud.

\section{REFERENSI}

Bigne, Alcaniz, et al. 2008. Influences of Online Shopping Information Dependency and Innovativeness on Internet Shopping Adaption. Online Information Review, Vol. 32 (5): 648-667.

Boone, L., \& Kurtz, D. 2007. Pengantar Bisnis Konteporer. Edisi Sebelas, Jakarta: Salemba Empat.

Ghozali, Imam. 2008. Structural Equation Modeling Metode Alternatif dengan Partial Least Square. Semarang: BP. Universitas Diponegoro.

. 2011. Aplikasi Analisis Multivariate dengan Program SPSS. Semarang: BP. Universitas Diponegoro.

Hume, M. \& Gillian, S.M. 2008. Satisfaction in Performing Arts: The Role of Value?. European Journal of Marketing. Vol. 42 (3/4): 311-326.

Kotler, Philip. 2008. Manajemen Pemasaran, Jilid 1 dan 2, Alih Bahasa Benyamin. Jakarta: PT. Indeks. Kelompok Gramedia. 
Maholtra, N.K. 2005. Riset Pemasaran: Pendekatan dan Terapan, Edisi 1. Jilid 1 dan 2. Jakarta: Indeks.

Muzahid, M.A. \& Noorjahan, P. 2009. Impact of Service Quality, Trust, and Customer Satisfaction on Customer Loyalty. ABAC Journal. Vol. 29. No. 1: 24-38.

Nielson. 2004. Pasar Modern Menyerbu, Pasar Tradisional Menyusut. www.dream.co.id/ dinar/serbuan-pasar-modern-susutkan-pertumbuhan-pasar-tradisional-141003d. html. diakses tanggal 2 Januari 2014.

Roig, dkk. 2006. Customer Perceived Value in Banking Services. International Journal of Banking Marketing. Vol. 24. Nomor 5: 266-283.

Santoso, S. 2007. Structural Equation Modeling: Konsep dan Aplikasi dengan AMOS. Jakarta: PT. Elex Media Komputindo.

Siregar, S. 2010. Statistika Deskriptif untuk Penelitian. Jakarta: Rajawali Pers.

Solvang, B.K. 2007. Satisfaction, Loyalty, and Repurchase: A Study of Norwegian Costumer Satisfaction, Dissatisfaction and Complaining Behaviour, Journal STIESIA. Vol 12.: 83-107.

Sugiyono. 2011. Statistika untuk Penelitian. Bandung: Alfabeta. . 2014. Metode Penelitian Kuantitatif, Kualitatif dan R\&D. Cetakan ke-20. Bandung: Alfabeta.

Suprapti, N.W.S. 2009. Perilaku Konsumen: Pemahaman Dasar dan Apliklasinya dalam Strategi Pemasaran. Denpasar: Udayana University Press.

Umar, Husein. 2009. Metode Penelitian untuk Skripsi dan Tesis Bisnis. Jakarta: Rajawali. 
